\title{
Online Education and Engineering Students' Perception of Pedagogical Quality, in Learning the Process Control Course with MATLAB
}

\author{
https://doi.org/10.3991/ijet.v16i21.25235 \\ Omar Chamorro-Atalaya $\left.{ }^{1}{ }^{\varpi}\right)$, Orlando Ortega-Galicio ${ }^{1}$, Guillermo Morales-Romero ${ }^{2}$, \\ Adrián Quispe-Andía ${ }^{2}$, Nicéforo Trinidad-Loli², Sofía Gamarra-Mendoza ${ }^{3}$, \\ César León-Velarde ${ }^{4}$ \\ ${ }^{1}$ Universidad Nacional Tecnológica de Lima Sur, Lima, Peru \\ ${ }^{2}$ Universidad Nacional de Educación Enrique Guzmán y Valle, Lima, Peru \\ ${ }^{3}$ Universidad San Ignacio de Loyola, Lima, Peru \\ ${ }^{4}$ Universidad Tecnológica del Peru, Lima, Peru \\ ochamorroduntels.edu.pe
}

\begin{abstract}
- the objective of this article is describing the results obtained from the evaluation of perception in engineering students, regarding pedagogical quality, in the context of online education; during the learning process of the process control course with Matlab. When developing the research, it was determined with respect to the answers capacity factor, that the indicators that present a better perception are "When presenting an observation about the development of the subject, the teacher responds to it appropriately" and "When you have any question or concern, the teacher answers your query quickly", which have a total agreement of $82.4 \%$. Regarding the Empathy factor, the indicator that presents a better perception is "The time in which the subject is taught is convenient for all students", which presents a total compliance of $72.7 \%$. Regarding the indicators that show the quality of the pedagogical service in general, it was determined that $75.7 \%$ perceive that teachers are always willing to help them and $81.8 \%$ perceives that teachers understand the specific academic needs of their students.
\end{abstract}

Keywords-Online education, engineering students', perception, pedagogical quality, process control, MATLAB

\section{Introduction}

Structured teaching-learning systems based on the use of information technologies and the internet require a redefinition of traditional models to guide a model with greater adaptability and flexibility [1,2]. In this regard, in [3,4], the authors point out that the use of information technologies in Latin American and Caribbean countries has been massifying in the educational system, even more so at the university level. However, it is urgent to develop pedagogical models under the scheme and application of virtual tools $[5,6]$. Thus, a problem is perceived in the pedagogical strategies used by 
teachers that many of them do not adapt to the use of virtual tools [7,8]. Virtually supposes a process of constant construction, of appropriation of knowledge, of adequacy of the teacher in aspects related to appropriate pedagogical strategies. In view of the above, it is important to reflect on the conditions of the health emergency in which the class sessions are held at the university level $[9,10]$. In this regard, in $[11,12]$, the authors point out that the teacher has a fundamental role in the possibility of articulating and giving meaning to learning through virtual environments, and in the adaptation of their pedagogical strategies to achieve effective teaching.

The general and almost obligatory adaptation to virtual education at this time makes it necessary to evaluate it permanently in order to guarantee the quality of the educational process and determine aspects to improve [13]. In this regard, in [14], the author points out that quality is a factor that distinguishes a university educational institution and provides it with a competitive advantage over other institutions. However, in [15], the author establishes that a factor that is linked to educational quality is teacher performance. The quality of teaching requires considering and working from several fronts, perhaps the most important is to improve the quality of the teacher [16].

In this sense, this article aims to describe the results obtained from the evaluation of perception in engineering students, regarding pedagogical quality, in the context of online education; during the learning process of the process control course with Matlab, of the professional school of mechanical and electrical engineering of the National Technological University of Lima Sur (UNTELS) of Peru.

\section{Investigation methodology}

\subsection{Research level and method}

The research level is descriptive, since it focuses on identifying the degree of satisfaction towards the answers capacity and empathy factors, which are part of the SERVQUAL model, this analysis is carried out under the qualitative method, tending to raise and build the concept of pedagogical quality from the perspective of the students of the automatic process control course.

\subsection{Sample design}

The sample design was based on the analysis of the perception of 66 students of the eighth cycle of studies and the automatic process control course; all these participants are students from the National Technological University of Lima Sur, from the professional school of mechanical and electrical engineering.

\subsection{Collection and validation of data and instrument}

As indicated in the previous paragraphs, two factors (answers capacity and empathy) of the SERVQUAL model were used, through a survey, which contained assessment 
levels from totally disagree (5) to totally agree (1). It was possible to know the perception of the 66 students. It should be noted that the survey indicators were adjusted to the current context of online education; likewise, for a concise analysis, table 1 and 2 show the indicators of both factors with their respective codes.

Table 1. Indicators of the answers capacity factor

\begin{tabular}{|l|c|}
\hline Code & Answer's capacity \\
\hline AC1 & $\begin{array}{c}\text { When presenting an observation about the development of the subject, the teacher responds to it } \\
\text { appropriately }\end{array}$ \\
\hline AC2 & When you have any questions or concerns, the teacher answers your query quickly \\
\hline AC3 & The teacher is always ready to help you \\
\hline AC4 & In general, teachers are always ready to help you \\
\hline
\end{tabular}

Table 2. Indicators of the Empathy factor

\begin{tabular}{|l|c|}
\hline Code & Empathy \\
\hline E1 & If you have any questions, the teacher is willing to give you personalized attention. \\
\hline E2 & The schedule in which the subject is taught is convenient for all students \\
\hline E3 & The teacher takes into consideration their expressed interests \\
\hline E4 & In the development of the subject, the teacher transmits that he cares about his academic needs \\
\hline E5 & In general, teachers understand the specific academic needs of their students \\
\hline
\end{tabular}

The validation of the instrument is given through [4,7]; while the validation of the collected data was carried out using the Cronbach's alpha statistic, using the SPSS v25 software, the result of which was 0.951 .

\section{Results and discussion}

\subsection{Description}

The subject of automatic process control is a specialty subject of the mechanical and electrical engineering professional career, and due to the context of the health emergency, it is currently developed virtually, under the online education scheme. The class sessions are structured under synchronous and asynchronous sessions; in the synchronous sessions, there is two-way communication between the teacher and the student, in such a way that by using meet-google, active and permanent interaction between the student and his classmates is achieved. In the face-to-face mode, so that the students achieve the competencies defined for each class session, use was made of equipment and experimentation instruments; However, due to the situation in which we find ourselves, the MATLAB simulation software and its libraries linked to automatic control are used to solve cases related to the thematic content defined in the syllabus of the course. Figure 1 shows the pedagogical tools used in the development of the subject under the online education model; in which the role of the student in the meaningful 
development of their own knowledge (interactive learning, student-centered learning and collaborative learning) is highlighted.

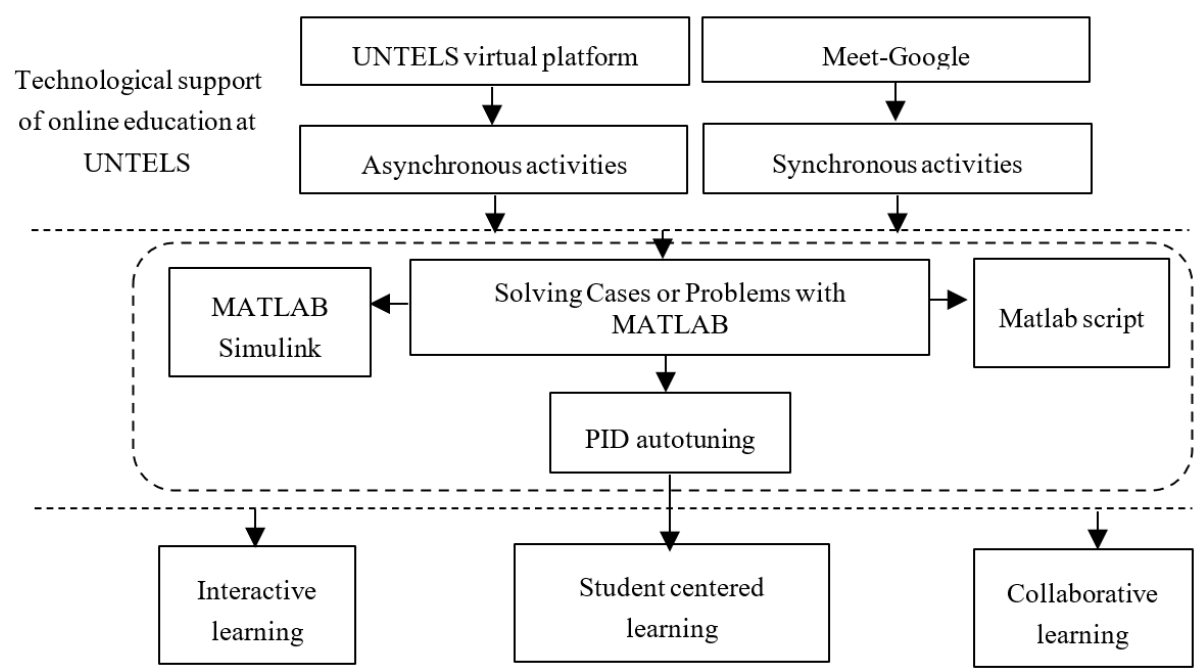

Fig. 1. Pedagogical strategy based on the use of virtual tools in online education

\subsection{Results}

Figure 2 shows the results, regarding the perception of the pedagogical quality of the teacher, according to the factors Response Capacity (AC) and Empathy (E).
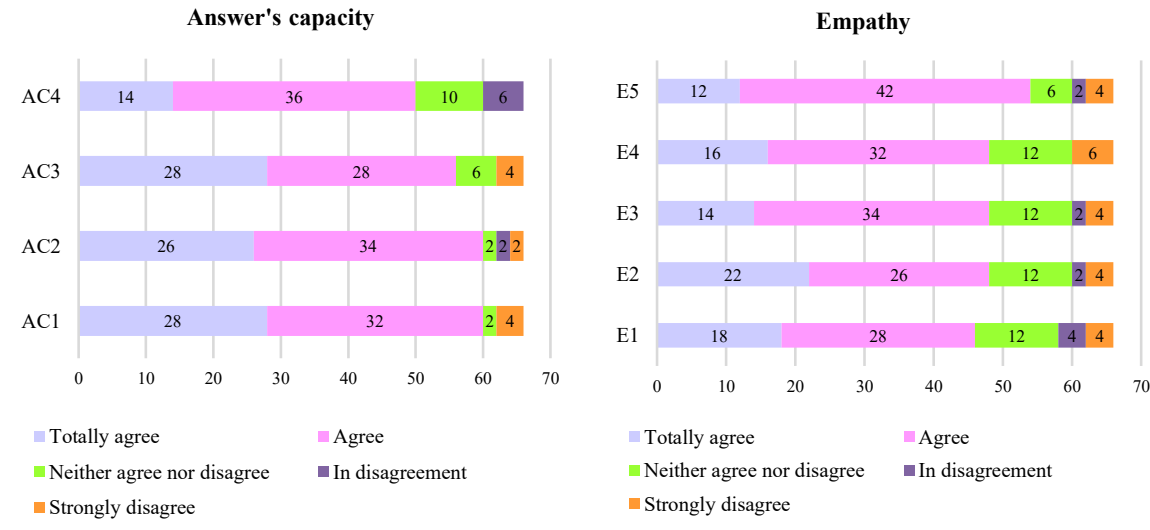

Fig. 2. Perception of pedagogical quality, according to the Answers Capacity and Empathy factors

The results of the Answers Capacity factor, illustrated in figure 2, reflect that indicators $\mathrm{AC} 1$ and $\mathrm{AC} 3$ are the ones that present the best perception by students, with 
$42.4 \%$ in complete agreement and more than $40 \%$ in agreement with compliance with these indicators. Next is the AC2 indicator, which presents an optimal perception of $39.4 \%$ who totally agree and $51.5 \%$ who agree. Although the results are favorable, there is a percentage that ranges between $3.0-9.1 \%$ of students who state that they disagree and totally disagree with these three indicators (AC1, AC2 and AC3). Regarding the AC4 indicator, which generally shows the pedagogical service from the point of view of response capacity, it was obtained that $75.7 \%$ perceive that teachers are always willing to help them, and $15.2 \%$ do not agree or disagree with this and $9.1 \%$ who perceive that this indicator is not developed adequately.

On the other hand, the results of the empathy factor, illustrated in figure 2, reflect that the E2 indicator is the one that presents a better perception by students, with $33.3 \%$ being in complete agreement and $39.4 \%$ in agreement with the compliance with this indicator. Next is indicator E1, which presents an optimal perception of $27.3 \%$ who totally agree and $42.4 \%$ who agree. Although the results are positive, there is a percentage that oscillates between $3.0-9.1 \%$, of students who state that they disagree and totally disagree, with the indicators E1, E2, E3 and E4. Regarding indicator E5, which generally shows the pedagogical service from the empathy point of view, it was obtained that $81.8 \%$ perceive that teachers understand the specific academic needs of their students, with $9.1 \%$ finding that they do not agree nor do they disagree with it and $9.1 \%$ who perceive that this indicator is not developed adequately.

Exposed the indicators that present the highest percentage of conformity in the pedagogical quality, the percentage relation of the same is determined. Regarding the Answers Capacity factor, table 3 shows the results of the perception that relates to indicator $\mathrm{AC} 1$ : "When presenting any observation about the development of the subject, the teacher responds to it appropriately" with indicator AC4: "In general, the teachers are always ready to help him". From table 3 we can highlight that, of the total of 66 students, two who totally agree with $\mathrm{AC} 1$, disagree with $\mathrm{AC} 4$, and 26 who agree with $\mathrm{AC} 1$, agree that they totally agree with AC4.

Table 3. Cross table between AC1 and AC4

\begin{tabular}{|c|c|c|c|c|c|c|}
\hline & \multicolumn{4}{|c|}{ AC4 } & \multirow[b]{2}{*}{ Total } \\
\hline & & In disagreement & $\begin{array}{l}\text { Neither agree } \\
\text { nor disagree }\end{array}$ & Agree & $\begin{array}{c}\text { Totally } \\
\text { agree }\end{array}$ & \\
\hline \multirow{5}{*}{$\mathrm{AC} 1$} & Strongly Disagree & $100 \%$ & $0.0 \%$ & $0.0 \%$ & $0.0 \%$ & $100 \%$ \\
\hline & Neither agree nor disagree & $0.0 \%$ & $100 \%$ & $0.0 \%$ & $0.0 \%$ & $100 \%$ \\
\hline & Agree & $0.0 \%$ & $18.8 \%$ & $81.3 \%$ & $0.0 \%$ & $100 \%$ \\
\hline & Totally agree & $7.1 \%$ & $7.1 \%$ & 35.7 & $50 \%$ & $100 \%$ \\
\hline & Total & $9.1 \%$ & $15.2 \%$ & $54.5 \%$ & $21.2 \%$ & $100 \%$ \\
\hline
\end{tabular}

Regarding the empathy factor, table 4 shows the results of the perception that relates to indicator E1: "Before any query, the teacher is willing to provide personalized attention" with indicator E5: "In general, teachers understand the academic needs specific to their students". 
Table 4. Cross table between E1 and E5

\begin{tabular}{|c|c|c|c|c|c|c|c|}
\hline & \multicolumn{5}{|c|}{ E5 } & \multirow[b]{2}{*}{ Total } \\
\hline & & \begin{tabular}{|l} 
Strongly \\
Disagree
\end{tabular} & In disagreement & $\begin{array}{l}\text { Neither agree } \\
\text { nor disagree }\end{array}$ & Agree & $\begin{array}{c}\text { Totally } \\
\text { agree }\end{array}$ & \\
\hline \multirow{6}{*}{ E1 } & Strongly Disagree & $50 \%$ & $50 \%$ & $0.0 \%$ & $0.0 \%$ & $0.0 \%$ & $100 \%$ \\
\hline & In Disagreement & $50 \%$ & $0.0 \%$ & $50 \%$ & $0.0 \%$ & $0.0 \%$ & $100 \%$ \\
\hline & Neither agree nor disagree & $0.0 \%$ & $0.0 \%$ & $16.7 \%$ & $83.3 \%$ & $0.0 \%$ & $100 \%$ \\
\hline & Agree & $0.0 \%$ & $0.0 \%$ & $7.1 \%$ & $85.7 \%$ & $7.1 \%$ & $100 \%$ \\
\hline & Totally agree & $0.0 \%$ & $0.0 \%$ & $0.0 \%$ & $44.4 \%$ & $55.6 \%$ & $100 \%$ \\
\hline & Total & $9.1 \%$ & $3.0 \%$ & $9.1 \%$ & $63.6 \%$ & $18.2 \%$ & $100 \%$ \\
\hline
\end{tabular}

From Table 4, we can highlight that, of the total of 66 students, 10 who state that they neither agree nor disagree with E1 agree with E5. Finally, eight who totally agree with E1 agree with E5 and two who agree with E1 state that they neither agree nor disagree with E5.

\subsection{Discussion of results}

As determined in the results, there is a high percentage of satisfaction with the quality of the pedagogical service, with $75.7 \%$ of the students in agreement with the teacher's Answers Capacity and $81.8 \%$ with the Empathy shown by the teacher in understanding your specific academic needs. These results can be related to what was obtained in [16], where a $25 \%$ acceptance was obtained that the criterion associated with the concern shown by the teacher for the students' learning and the clarification of their doubts, is found in the third place of priorities.

Likewise, the results respond to the research of [17] where, based on the study, a provisional model of quality education is built, articulated around three levels, which define the evaluation and support strategies for quality. The proposed model is built on the basis of a first level called essential, which serves as a pillar for the subjective construction around the topic, and fundamentally includes commitment and personal concern for students. The second level, called formative, includes the delivery of values and life skills. The third level, for its part, called instrumental, includes learning achievements and components of school management. Based on these results, it is possible to hypothesize about the influence that the subjective dimension of the concept of quality education may have on the perception and appropriation that educational actors make of the programs and policies aimed at strengthening it.

Similarly, regarding the quality of the teaching service in [16], it is pointed out that the criterion mastery of the topics, subjects or subjects worked on in the semester obtains $37 \%$ acceptance with a priority criterion, also the criterion of mastery of Teaching strategies has $45 \%$ acceptance, obtaining the practical criteria of values, such as punctuality, responsibility, empathy, honesty, sincerity, a prioritization assessment of $33 \%$.

It should be noted that, as part of the pedagogical quality, in [11] it is indicated that, in addition to the interest in the needs shown by the teachers, the strategies and didactic 
tools incorporated in the teaching process are very important, since All of this is essential for the educational actors interviewed, resulting in their perception relevant to providing quality education.

\section{Conclusions}

The research determines that despite this context of online education, most students positively perceive the Answers Capacity and Empathy of teachers, feeling satisfied with the ability that they understand their specific academic needs and the doubts or concerns that arise. presented during the development of the subjects, the results of this analysis are of great importance for the higher institution, since in order to achieve the quality of the pedagogical service, the strengths and weaknesses within the institution must be known, being a vital point to take into account the perception of students even more if in various investigations they relate satisfaction with academic performance, with the results obtained it is suggested to develop strategic plans for continuous improvement of educational quality, making all actors part of the teaching process learning, being necessary to provide the teacher with a ret feedback of its performance according to the information provided by the analyzes carried out.

\section{$5 \quad$ Acknowledgment}

Thanks to the National Technological University of Lima Sur.

\section{References}

[1] Vásquez-Ponce, G., Indacochea-Figueroa, J., Forty-Moreira, R., and Chara-Plúa, E. (2020). Virtual education in times of covid-19 from the socioeconomic perspective of the students of the southern state university of Manabí in the Jipijapa canton. Knowledge Pole Journal, 5 (2), 754-773.

[2] Yee-Kiaw, L., Sook-Liang, L. and Siong-Hoe, L. (2020). An empirical study of students' intention to use cloud e-learning in higher education. International Journal of Emerging Technologies in Learning (iJET), 15 (9), 19-38, https://doi.org/10.3991/ijet.v15i09.11867

[3] Mendieta, G., Coronel, M., Marín, M. and Coronel, D. (2019). Virtual classrooms as a pedagogical measurement for inclusion and disabilities. Publications Journal, 50 (2), 31-39, https://doi.org/10.30827/publicaciones.v50i2.13941

[4] Páez, M. (2019). Optimization of the pedagogical process and teaching management: a look at virtual learning environments. Journal Research Gate 12(1), 1-7, https://doi.org/10. 13140/RG.2.2.35697.63845

[5] Ortiz, W., Santos, L. and Rodríguez, E. (2020). Didactic strategies in virtual university teaching-learning environments. Opuntia Brava Journal, 12 (4), 68 -83.

[6] Delerna, G., Lévano, D. (2021). Importance of information technologies in strengthening pedagogical skills in times of pandemic. Scientific Journal of Systems and Informatics. 1(1), 69-78, https://doi.org/10.51252/rcsi.v1i1.104

[7] Sanchez, J., Gonzáles, A., Monroy, A. (2019). The training of normalista teachers: from the pedagogical tradition to virtual learning environments. Iberoamerican Journal for Educational Research and Development. 10(19), 78-86, https://doi.org/10.23913/ride.v10i19.539 
[8] Parra, J. (2020). Traditional teaching practices in virtual education environments. Academic Journal and Virtuality. 13(1), 93-106, https://doi.org/10.18359/ravi.4295

[9] Ojeda-Beltrán, A., Ortega-Álvarez, D. and Boom-Carcamo, E. (2020). Analysis of the perception of face-to-face students about virtual classes in response to the Covid-19 crisis. Journal Spaces. 41(42), 81-91, https://doi.org/10.48082/espacios-a20v41n42p07

[10] Buitrago-Bohorquez, B. and Sanchez, H. (2021). Pedagogical and technological competences of the teacher for the instructional design in virtual university education. IPSA Journal. 6(2), 82-100, https://doi.org/10.25214/27114406.1054

[11] Barbera, N., Hernández, E. and Vega, A. (2020). Challenges of pedagogical management in virtuality in the face of the covid-19 crisis. Disciplinary journal in economic and social sciences. 2(1), 43-48, https://doi.org/10.47666/summa.2.esp.05

[12] Zi-Yu, L., Lomovtseva, N. and Korobeynikova, E. (2020). Online learning platforms: Reconstructing modern higher education. International Journal of Emerging Technologies in Learning (iJET), 15 (13), 4-21, https://doi.org/10.3991/ijet.v15i13.14645

[13] Shraim, K. (2020). Quality standars in online education: the ISO/IEC 40180 Framework. International Journal of Emerging Technologies in Learning (iJET), 15 (19), 22-36, https://doi.org/10.3991/ijet.v15i19.15065

[14] Martínez, D., Pérez, A., Pat, L. and García, J. (2020). Importance of quality in the public university. The perception of the student at the Autonomous University of Carmen. Iberoamerican Journal for Educational Research and Development. 10(20), 1-20, https://doi.org/10.23913/ride.v10i20.658

[15] Gálvez, E. and Milla, R. (2018). Evaluation of teaching performance: preparation for student learning within the framework of good teaching performance. Purposes and Representations Journal. 6(2), 407-452.

[16] Cóndor-Quimbita, B. and Remache-Bunci, M. (2019). The evaluation of managerial and teaching performance as an opportunity to improve educational quality. Cátedra Journal. 2(1), 116-131, https://doi.org/10.29166/catedra.v2i1.1436

[17] J. Montenegro, "Quality in university teaching. An approximation from student's perception", Education, vol. 29, no. 56, pp. 116-145, 2020, https://doi.org/10.18800/educacion.202001.006

[18] J. Záhoree, A. Nagyová and A. Hasková, "How is "quality education" defined by principals and teachers?", Quality in education, vol. 1, no. 43, pp. 103-145, 2015.

\section{$7 \quad$ Authors}

Omar Freddy Chamorro Atalaya and Orlando Adrian Ortega Galicio, Teachers at the National Technological University of Lima Sur (UNTELS), Lima, Peru.

Guillermo Pastor Morales Romero, Adrian Quispe Andía and Nicéforo Trinidad Loli, Teachers at the Enrique Guzman y Valle National University of Education (UNE), Lima, Peru.

Sofía Gamarra Mendoza, Teacher at the Saint Ignatius of Loyola University (USIL), Lima, Peru.

César León Velarde, Teacher at the Technological University of Peru (UTP), Lima, Peru.

Article submitted 2021-07-03. Resubmitted 2021-08-17. Final acceptance 2021-08-19. Final version published as submitted by the authors. 